Check for updates

Cite this: RSC Adv., 2019, 9, 27190

Received 18th April 2019

Accepted 5th August 2019

DOI: $10.1039 / c 9 r a 02920 f$

rsc.li/rsc-advances

\section{Electro-dewatering pretreatment of sludge to improve the bio-drying process}

\author{
Li Sha, (D) ${ }^{a}$ Xiaoyan Yu, ${ }^{b}$ Xingxin Liu, ${ }^{a}$ Xiaotong Yan, ${ }^{a}$ Jingxiao Duan, ${ }^{a}$ Yingte $\mathrm{Li}^{\mathrm{a}}$ \\ and Shuting Zhang (D) *a
}

In this study, the feasibility of electro-dewatering (EDW) as a pretreatment of the subsequent bio-drying process (EB process) was investigated from the point of view of the influence of EDW on the microbial biodegradability of sludge. The results showed that suitable EDW pretreatment was beneficial for microbial growth in the sludge cake, and in the subsequent bio-drying process it increased the metabolic activity of microorganisms. However, electric field strength impacted microbial activity and soluble chemical oxygen demand (SCOD) of the sludge. As the applied electric field strength increased from 20 to $60 \mathrm{~V} \mathrm{~cm}^{-1}$, the microbial activity of sludge decreased gradually but SCOD of sludge increased. The specific oxygen uptake rate (SOUR) at electric field strength of $20 \mathrm{~V} \mathrm{~cm}^{-1}$ was $8.7 \%$ higher than that of raw sludge. EDW pretreatment accelerated the drying rate of bio-drying process, and the final water content of sludge (44\%) was $6.3 \%$ lower than that of non-pretreated sludge. It was observed that in the bio-drying process with an EDW pretreatment, the first peak temperature of the sludge pile was $58.7^{\circ} \mathrm{C}$ at $36 \mathrm{~h}$ and the second peak temperature was $48.7^{\circ} \mathrm{C}$ at $56 \mathrm{~h}$, whereas that of the non-pretreated sludge was only $46.5^{\circ} \mathrm{C}$ at $42 \mathrm{~h}$ and $40.3^{\circ} \mathrm{C}$ at $62 \mathrm{~h}$, respectively. The EDW sludge incorporating straw as a bulking agent showed promising results during bio-drying. In addition, EDW pretreatment of sludge to improve the bio-drying process showed lower energy consumption and cost.

\section{Introduction}

In China, with rapidly accelerated urbanization in the recent decades, an increasing number of wastewater treatment plants (WWTPs) have been built to cope with the increasing sewage production of growing urban populations, and a large quantity of sewage sludge is produced. ${ }^{1}$ Sludge treatment and disposal accounts for approximately half of the operating costs of WWTPs. ${ }^{2}$ With more stringent legislation for the protection of the environment, the cost of sludge disposal has increased, and it depends directly on the volume of sludge to be treated and its water content. ${ }^{3}$ Currently mechanical pressure or centrifugation is widely used. However, it is not easy to attain high dehydration and sometimes the moisture content (MC) of sludge cakes reaches as high as $80 \%{ }^{4,5}$ Therefore, for mechanically dewatered sludge, a deeper dewatering is necessary for the significant savings for both operation costs and land applications. ${ }^{6}$

Deep dewatering of sludge dewatered mechanically includes various methods such as thermal drying, lime conditioning, composting, bio-drying, and electro-dewatering (EDW). Thermal drying is a traditional but efficient method that can

${ }^{a}$ School of Environment Science and Engineering, Tianjin University, Tianjin 300354, China. E-mail: zhangst@tju.edu.cn; Fax: +86 15802211798; Tel: +86 15802211798

${ }^{b}$ School of Energy and Chemical Engineering, Liaoning Technical University, Huludao 125105, China provide good control and achieve high dryness. However, high consumption of a nonrenewable energy resources and complicated apparatus lead to high operating and investment costs. ${ }^{7-9}$ Adding lime can speed up the sludge dewatering process, but the uses of inorganic and chemical conditioners not only result in incomplete combustion, equipment corrosion, and secondary pollution, but also greatly reduce the heat value of sludge cakes. ${ }^{10}$ Composting is an economical and effective biotechnology for sludge stabilization that can inactivate pathogens and convert organic pollutants into a humidified product. However, nitrous oxide $\left(\mathrm{N}_{2} \mathrm{O}\right)$, which has a global warming potential that is 298 times greater than an equivalent mass of $\mathrm{CO}_{2}$, is produced during the composting process. ${ }^{11}$ Lastly, the bio-drying method, which is similar to composting, is a solid-state aerobic process that degrades the easily biodegradable organic fraction in the waste. During this process, heat produced by microbial activities, with an adequate airflow-rate, enables fast evaporation of moisture. ${ }^{12}$ Bio-drying does not require an additional heat source and is an economical and energy-saving technology for deep dewatering of sludge. ${ }^{13}$ However, sludge dewatered mechanically cannot be treated by bio-drying alone, because its high MC and small particle size can lead to reduced gas permeability. ${ }^{14}$ Another deep dewatering method is EDW; by delaying the application of the electric field to the filter cake compression stage, potential savings in power consumption, of approximately $10-12 \%$ in the case of 
constant voltage and approximately $30-46 \%$ under constant current, were attained. ${ }^{3}$ When sludge cakes are compressed between an anode plate and a cathode net filled with an electric field of dozens of volts per centimeter, water in the sludge falls through the cathode net as filter liquor. After only minutes of the EDW treatment, the MC of sludge can decrease from $80 \%$ to $60 \%$ with a lower energy consumption. ${ }^{15,16}$ The EDW process has gained increasing attention and has been widely studied in recent years owing to its high efficiency and low energy consumption. ${ }^{17-20}$ However, at the terminal stages of EDW when the water content is less than $55-60 \%$, the electric energy consumption increases sharply. ${ }^{21,22}$

Hence to resolve the low dewatering efficiency at the terminal stages of EDW and higher MC and small particle size at the start of bio-drying process, a deeper dewatering method of EDW pretreatment improving bio-drying has been proposed. In our previous study, Li et al. ${ }^{13}$ investigated the effects of the deep dewatering process combining EDW instead of bulking agent with bio-drying by the optimization of various parameters of EDW process. They showed that the MC decreased to $41.92 \%$ in the dewatered sewage sludge bio-dried after EDW. However, addition of inoculation and bulking agents is required to increase the stability of bio-drying process for industrial applications. Moreover, EDW could reduce the bacterial pathogens in wastewater sludge. ${ }^{23}$ At present, both systematic research and basic evaluations of EDW pretreatment to improve the biodrying process are very scarce. Thus, the objective of this research was to investigate the performance of bio-drying for sludge pretreated by EDW, from the perspective of the influence of EDW on sludge biodegradability. Firstly, the biodegradability and microbial activity of sludge were evaluated after EDW by investigating the soluble chemical oxygen demand (SCOD), volatile fatty acids (VFAs), microbial culture, and specific oxygen uptake rate (SOUR). Then, the performance of EDW pretreatment of sludge to improve the bio-drying process was investigated, and the bulking agents were optimized. Finally, the energy consumption and costs of the entire process were analyzed.

\section{Materials and methods}

\subsection{Experimental set-up}

The experimental set-up for EDW is shown in Fig. 1a, which has previously been described by Zhang et al. ${ }^{24}$ A pressure of 2 bar was applied to ensure the close electrical contact between anode and sludge. The experimental set-up for bio-drying is shown in Fig. 1b. The column reactor $(400 \mathrm{~mm}$ in height, $300 \mathrm{~mm}$ in internal diameter) was made of polymethyl methacrylate. The double-layer thermal insulation (40 $\mathrm{mm}$ in thickness), made of nitrile butadiene rubber and polyvinyl chloride, was wrapped around the outer wall of column. The three thermocouples were inserted at the top, the middle, and the bottom of sludge bed to monitor the corresponding temperature, and the transient temperature was recorded every $2 \mathrm{~h}$ using a computer. A perforated baffle, with $3 \mathrm{~mm}$ inner diameter of aeration pores, was fixed at $40 \mathrm{~mm}$ distance from the bottom of column to support the materials and facilitate aeration. A metal mesh (10 mesh) was placed on the perforated plate to prevent the sludge particles leaking down the bottom of the column. The air was pumped into the bottom of the column by a gas-flow meter. The sludge in the column was mixed every day before sampling.

\subsection{Sludge samples and bulking agents}

The sludge for deeper dewatering in this study was obtained from Tianjin Jingu Wastewater Treatment Plant (China). The MC and volatile solids (VS) of the sludge were approximately $79.8 \%$ and $54 \%$, respectively. Sludge samples were kept in plastic bags and stored at $4{ }^{\circ} \mathrm{C}$, and used within one week. For VFAs analysis, the feeding sludge used in anaerobic digestion (ADIS), was obtained from the anoxic pond in the anaerobicanoxic-oxic (AAO) process of the Tianjin Jizhuangzi Wastewater Treatment Plant (China). Composting products (CP), which were used as inoculums for bio-drying, were obtained from Tangshan Fengrun Wastewater Treatment Plant (China).

Bulking agents such as straw, sawdust, and plastic foam (Qikang Water Treatment Materials Limited) were used for biodrying. The MC, VS, and particle size of the straw were $13 \%$, 89\%, and 5-15 $\mathrm{mm}$, respectively. The MC, VS, and particle size of the sawdust were $6 \%, 82 \%$, and less than $2 \mathrm{~mm}$, respectively. The particle size of the plastic foam was $2-4 \mathrm{~mm}$.

\subsection{Experimental methods}

$1200 \mathrm{~g}$ sludge cake dewatered by filtration and compression was used for each electro-dewatering test. The electric field strength was used in a series of 20,40 and $60 \mathrm{~V} \mathrm{~cm}^{-1}$. EDW was stopped when the MC of the sludge cakes decreased to approximately $65 \%$. As a control, a sludge with no electro-dewatering pretreatment was air-dried in a fume hood to the same MC with the sludge by EDW to eliminate the differences caused by the initial water content in the subsequent bio-drying tests.

The sludge prepared for bio-drying amounted to $16 \mathrm{~kg}$. During the six-day bio-drying period, the sludge was turned every two days to ensure homogenization. A time-based aeration control system was adopted for intermittent air supply with a frequency of $3 \mathrm{~min} \mathrm{run} / 7 \mathrm{~min}$ stop. The air flow rate was 0.08 $\mathrm{m}^{3}\left(\mathrm{~h}^{-1} \mathrm{~kg}^{-1}\right)$, that is, the ventilation volume was $0.08 \mathrm{~m}^{3}$ per hour per kilogram of sludge.

\subsection{Analysis methods}

The MC and VS contents were measured by drying at $105^{\circ} \mathrm{C}$ for $24 \mathrm{~h}$ and $550{ }^{\circ} \mathrm{C}$ for $4 \mathrm{~h}$, respectively. For SCOD analysis, $5 \mathrm{~g}$ sludge samples were placed in a conical flask containing $50 \mathrm{~mL}$ ultra-pure water and oscillated for $4 \mathrm{~h}$. Then the sludge suspension was centrifuged at $8000 \mathrm{rpm}$ for $5 \mathrm{~min}$, and the supernatant filtered through the $0.45 \mu \mathrm{m}$ membrane was used for analyzing the chemical oxygen demand (COD) according to the standard method described by Hua et al. ${ }^{25}$ During VFAs analysis, the samples were centrifuged at $10000 \mathrm{rpm}$ for $8 \mathrm{~min}$. The supernatant was filtered through $0.45 \mu \mathrm{m}$ membrane, and the VFA content was determined by a liquid chromatography system equipped with a Refractive Index Detector and a BioRad Aminex HPX-87H chromatographic column $(300 \times 7.8 \mathrm{~mm})$. The column temperature was $65{ }^{\circ} \mathrm{C}$. The mobile phase was 


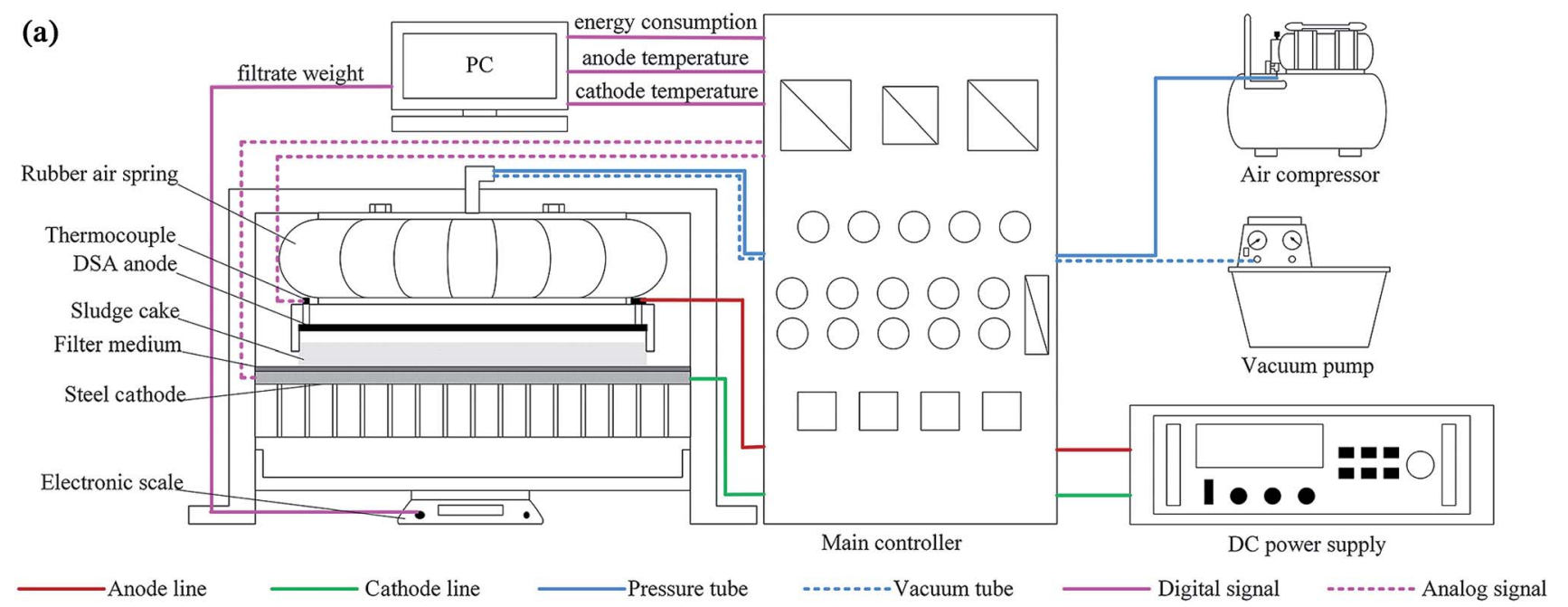

(b)

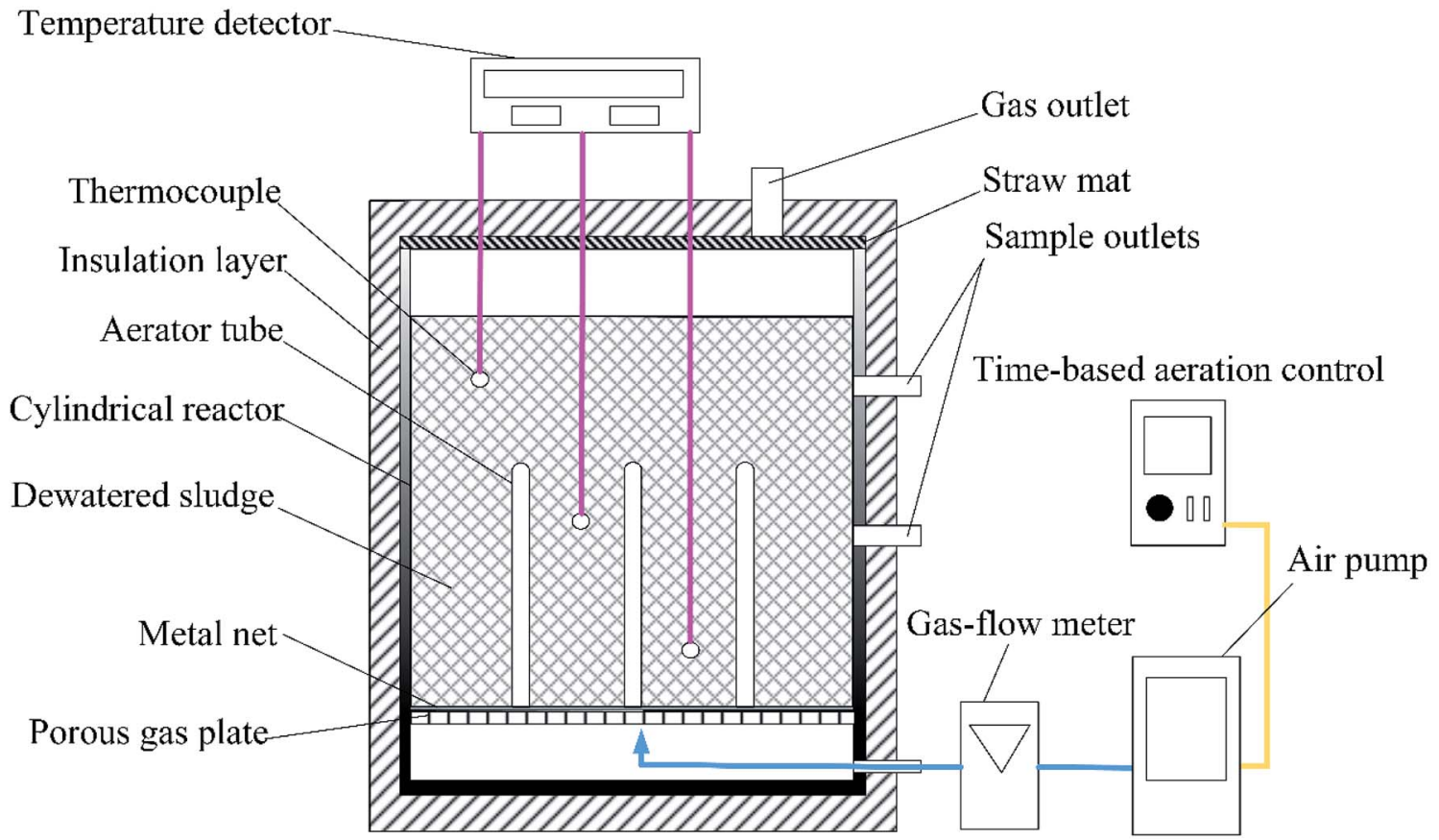

Air line

Digital signal

On-off input

Fig. 1 Schematic of (a) the EDW experimental equipment and (b) the bio-drying experimental equipment.

$5 \mathrm{mmol} \mathrm{L}^{-1} \mathrm{H}_{2} \mathrm{SO}_{4}$ solution as a flow rate of $0.6 \mathrm{~mL} \mathrm{~min}^{-1}$. SOUR was measured by the method described by Hua et al. ${ }^{25}$ and dissolved oxygen (DO) was monitored by a HQ40d portable meter (HACH, USA).

\section{Results and discussion}

\subsection{Effect of EDW on sludge biodegradability}

3.1.1 Effect of EDW on SCOD. As shown in Fig. 2a, the SCOD of sludge after EDW increased with increasing electric field strength. The SCOD of sludge with non EDW pretreatment (raw sludge) was $29.3 \mathrm{mg} \mathrm{g}^{-1} \mathrm{TS}$. When the three electric field strengths of 20,40 and $60 \mathrm{~V} \mathrm{~cm}^{-1}$ were applied, the SCOD of EDW sludge was 1.3, 3.2 and 4.4 times than that of the raw sludge, respectively. Organic matter in sludge is typically covered by microorganism cell walls, which severely affects the biodegradability of the sludge. ${ }^{26,27}$ These cells can be destroyed by sufficient electric field strength. In addition, a greater electric field strength leads to more cells being destroyed, ${ }^{28}$ resulting in the release of some intracellular substances such as polysaccharides, proteins, and other organics, causing an increase in SCOD. ${ }^{29}$ In addition, the EDW pretreatment system is 
(a)

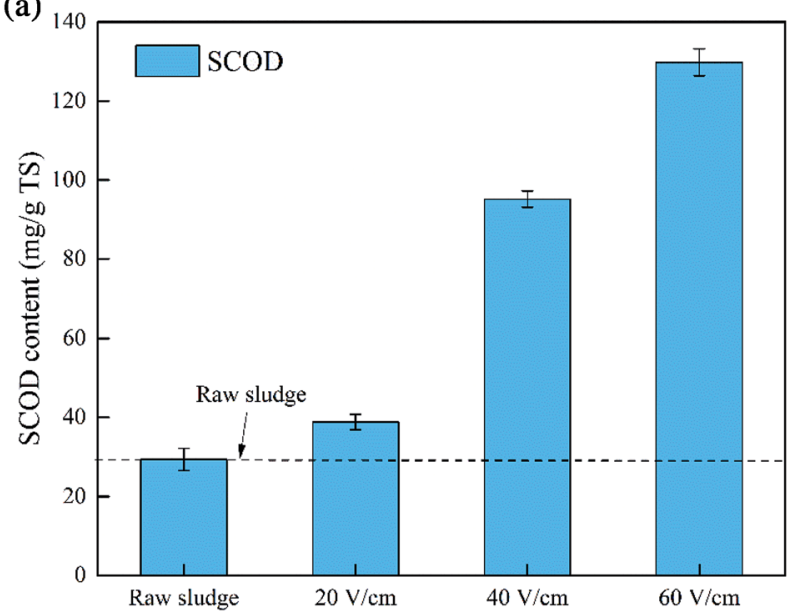

(b)

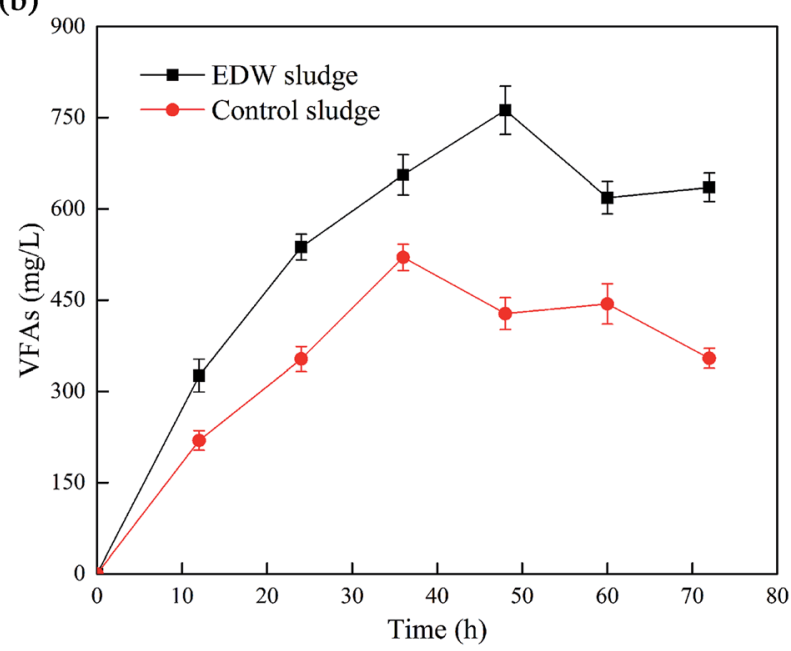

Fig. 2 Changes in (a) SCOD and (b) VFAs accumulation.

essentially an electrochemical cell. The application of an electric field strength produces electrochemical reactions which affect the performance of the sludge bed near the electrodes. The possible cathode and anode reactions are: ${ }^{15}$

At the cathode:

$$
\begin{aligned}
& 2 \mathrm{H}_{2} \mathrm{O}_{(\mathrm{l})}+2 \mathrm{e}^{-} \rightarrow 2 \mathrm{OH}_{(\mathrm{aq})}^{-}+\mathrm{H}_{2(\mathrm{~g})}, \quad E_{\mathrm{H}_{2} / \mathrm{H}_{2} \mathrm{O}}^{0}=-0.83 \mathrm{~V} \\
& 2 \mathrm{H}_{3} \mathrm{O}_{(\mathrm{aq})}++2 \mathrm{e}^{-} \rightarrow 2 \mathrm{H}_{2} \mathrm{O}_{(\mathrm{l})}+\mathrm{H}_{2(\mathrm{~g})}, \quad E_{\mathrm{H}_{2} / \mathrm{H}_{3} \mathrm{O}^{+}}^{0}=0 \mathrm{~V}
\end{aligned}
$$

At the anode:

$$
\begin{gathered}
\mathrm{M}_{(\mathrm{s})} \rightarrow \mathrm{M}_{(\mathrm{aq})}{ }^{n+}+n \mathrm{e}^{-} \\
6 \mathrm{H}_{2} \mathrm{O}_{(\mathrm{l})} \rightarrow 4 \mathrm{H}_{3} \mathrm{O}_{(\mathrm{aq})}^{+}+\mathrm{O}_{2(\mathrm{~g})}+4 \mathrm{e}^{-}, E_{\mathrm{H}_{2} \mathrm{O} / \mathrm{O}_{2}}^{0}=1.23 \mathrm{~V}
\end{gathered}
$$

Reaction (1) produces hydroxide ions and reaction (4) produces protons, this may result in a $\mathrm{pH}$ gradient across the sludge bed. Acidic or alkaline environment could promote the solubilization or degradation of extracellular polymeric substances (EPS) in sludge, and the organic matters such as polysaccharides and proteins resulting from broken sludge wall are released into the sludge suspension,,$^{30}$ causing a rapid increase of sludge SCOD. The $\mathrm{pH}$ gradient in the sludge cake was intensified concomitantly with the electric field strength, and the organic substance of EDW sludge were released in increased amounts (seen in Fig. 2a). It indicates that EDW sludge could provide a substantial amount of substrate consumed directly by microbes.

3.1.2 Effect of EDW on VFAs. The EDW sludge samples were placed into an anaerobic fermenter $(800 \mathrm{~mL}$ effective working volume) at $37{ }^{\circ} \mathrm{C}$ with a mass ratio of $4: 1$ between EDW sludge and the ADIS; control sludge was also treated simultaneously. After a start-up period of $72 \mathrm{~h}$ (Fig. 2b), VFAs accumulation in both the EDW sludge fermentation liquid (VFAs-EDW) and control sludge fermentation liquid (VFAscontrol) first increased, and then decreased with time. VFAsEDW reached a maximum of $762 \mathrm{mg} \mathrm{L}^{-1}$ after $48 \mathrm{~h}$, while VFAs-control reached $520.2 \mathrm{mg} \mathrm{L}^{-1}$ after $36 \mathrm{~h}$. VFAs-EDW was $241.8 \mathrm{mg} \mathrm{L}^{-1}$ higher than that of VFAs-control. The electroosmosis was able to rupture the cell wall and release intracellular substances, such as carbohydrates and proteins into the liquid phase, ${ }^{31}$ which increased the substrates in sludge available to microorganisms. This finding agrees with previous reports that solubilization of sludge contributes to increased VFAs in hydrolysate. ${ }^{32}$ VFAs-EDW reached a maximum $12 \mathrm{~h}$ later than VFAs-control; it may be due to the organic matter released from the microbiological cells ruptured by EDW, which has a high molecular weight and is difficult to decompose. In the later stage, VFAs-EDW and VFAs-control both exhibited a downward trend, possibly owing to the conversion of some VFAs into methane by microbes. At $72 \mathrm{~h}$, VFAs-EDW and VFAs-control decreased by $16.6 \%$ and $31.9 \%$, respectively.

3.1.3 Sludge performance in microbial culture. The microorganism cultivation experiment was conducted with the sludge itself as the medium and the microorganisms in the sludge as the strain. After three days as a biological medium at a constant temperature of $25{ }^{\circ} \mathrm{C}$ in a biological incubator, the sludge after EDW and the untreated control sludge, with the same size $(75 \mathrm{~mm} \times 60 \mathrm{~mm})$, were easily distinguished by microorganism growth (Fig. 3). The microorganisms in the untreated control sludge proliferated slowly and only several white speckles appeared, but the sludge after EDW was covered by innumerable colonies. It is possible that the evolution of gas (oxygen and hydrogen) at both electrodes led to the appearance of void space within the bed and increased the surface to environment of the system. This confirmed that the sludge after EDW was more suitable for microbial growth, which was favorable for subsequent biological treatment.

3.1.4 Changes in microbial activity. The specific oxygen uptake rate (SOUR) is an important index for evaluating the microbial activity of sludge..$^{33}$ It is measured by the amount of oxygen consumed per unit time by a unit mass of sludge. The sludge contains various types of microorganisms such as bacteria and fungi, ${ }^{34}$ some of which are the source of subsequent biological treatments.

As observed in Fig. 4, when the applied electric field strength increased from $20 \mathrm{~V} \mathrm{~cm}^{-1}$ to $60 \mathrm{~V} \mathrm{~cm}^{-1}$, SOUR of sludge after 


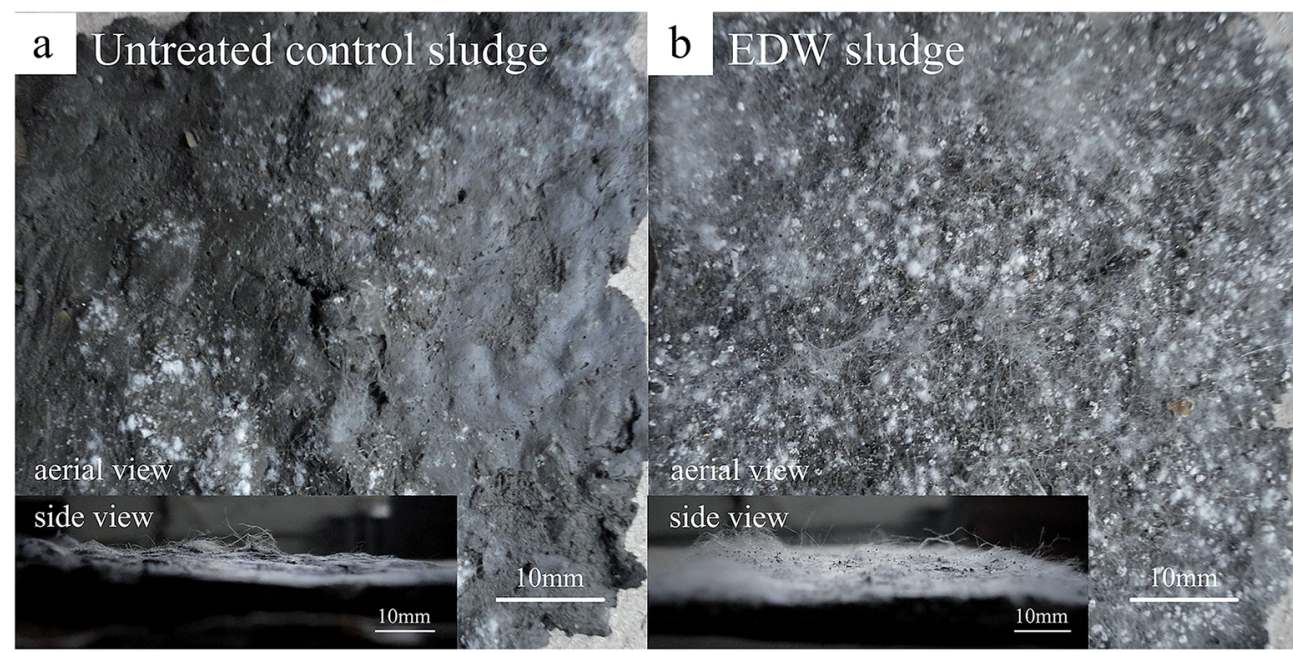

Fig. 3 Performance of (a) untreated control sludge and (b) EDW sludge after microbiological culture.

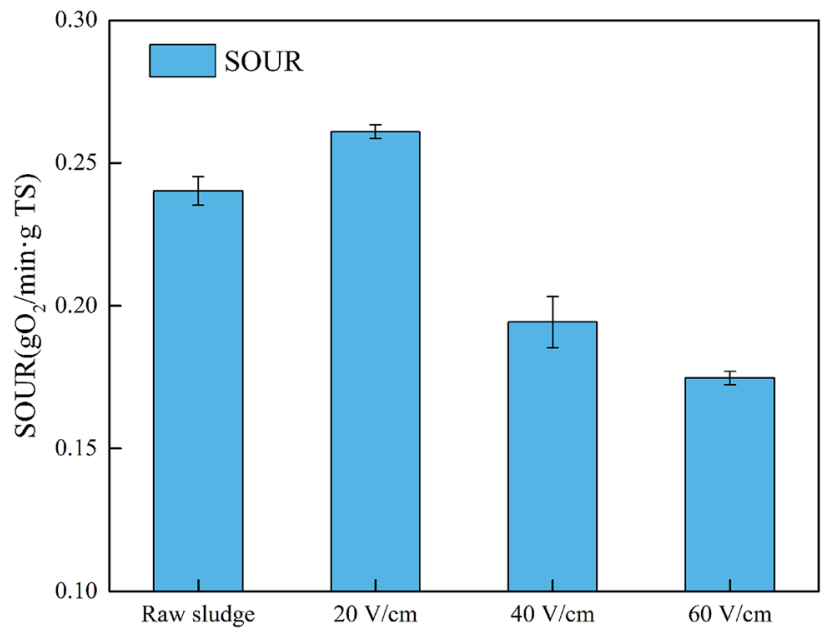

Fig. 4 Effect of EDW on the SOUR of sludge.

EDW decreased from $0.26 \mathrm{~g} \mathrm{O}_{2}$ per min per $\mathrm{g}$ TS to $0.17 \mathrm{~g} \mathrm{O}_{2}$ per min per $\mathrm{g}$ TS, and at the electric field strength of $20 \mathrm{~V} \mathrm{~cm}^{-1}$ it was $8.7 \%$ higher than that of raw sludge. This confirmed the findings of Nakanishi et al. ${ }^{35}$ who claimed that the electrostimulation of cells induced changes in DNA and protein synthesis, membrane permeability, and cell growth, that, at lowlevel current, can enhance bacterial activity and metabolism. Ibeid et $a .^{36}$ also reported that a low-level current would maintain microbial activity. However, at the electric field strength of $40 \mathrm{~V} \mathrm{~cm}^{-1}$ and $60 \mathrm{~V} \mathrm{~cm}^{-1}$, SOUR of sludge after EDW decreased by $19.1 \%$ and $27.3 \%$ compared to that of control sludge, respectively, which is the opposite trend to that of the SCOD variation of sludge. This verified that higher electric field intensity would generate more serious cracking effects in the microorganisms, releasing more organics from the sludge cells. As a result, in EDW pretreatment, the electric field strength of $20 \mathrm{~V} \mathrm{~cm}^{-1}$ was suitable for the subsequent bio-drying.

\subsection{Effect of EDW on the bio-drying process}

3.2.1 Changes in temperature, MC, and VS content during bio-drying. Temperature is an important parameter for water evaporation and organic matter degradation in sludge during bio-drying. ${ }^{9}$ Higher temperature facilitates the water molecules off the solid particles of sludge, but too high temperature would cause the activities of microorganisms to decline. Generally, the optimum temperature ranges for mesophilic bacteria and thermophilic bacteria are approximately $30-40{ }^{\circ} \mathrm{C}$ and $50-70{ }^{\circ} \mathrm{C}$, respectively, ${ }^{37-39}$ within which higher temperature can significantly improve the bio-drying process.

As observed in Fig. 5a, the first peak temperature of sludge pile after EDW was $58.7^{\circ} \mathrm{C}$ after $36 \mathrm{~h}$ of bio-drying, whereas that of the control sludge pile was only $46.5{ }^{\circ} \mathrm{C}$ after $42 \mathrm{~h}$. After the first homogenization of sludge, the second peak temperature of sludge pile after EDW remained high at $48.7{ }^{\circ} \mathrm{C}$ after $56 \mathrm{~h}$, whereas that of the control sludge pile was $40.3{ }^{\circ} \mathrm{C}$ after $62 \mathrm{~h}$. Clearly, the sludge pile after EDW had a faster drying rate and higher peak temperature than the control sludge pile, probably because the EDW pretreatment improved sludge disintegration and provided more soluble substances for the microorganisms. This was more conducive for the metabolic activity of the microorganisms, and thus more heat was produced. Furthermore, it was observed that the sludge after EDW due to the gas produced by electrochemical reactions formed particles more easily, resulting in a higher porosity and more uniform ventilation. This would create a favorable aerobic condition for the microbial activity in the bio-drying process.

Moreover, the MC of sludge after EDW decreased faster than the MC of the control sludge (Fig. 5b). After $144 \mathrm{~h}$, the MC of sludge after EDW was $44 \%$, which was $6.3 \%$ lower than the control sludge. According to Ma et al. and Velis et al., ${ }^{\mathbf{4 0 , 4 1}}$ these results may be attributed to the fact that higher microbial activity of sludge pile after EDW produces more heat, which increases the matrix temperature; the resulting higher temperature $\left(T>50{ }^{\circ} \mathrm{C}\right)$ effectively promotes water evaporation. Additionally, owing to the lysis of sludge after EDW, intracellular 

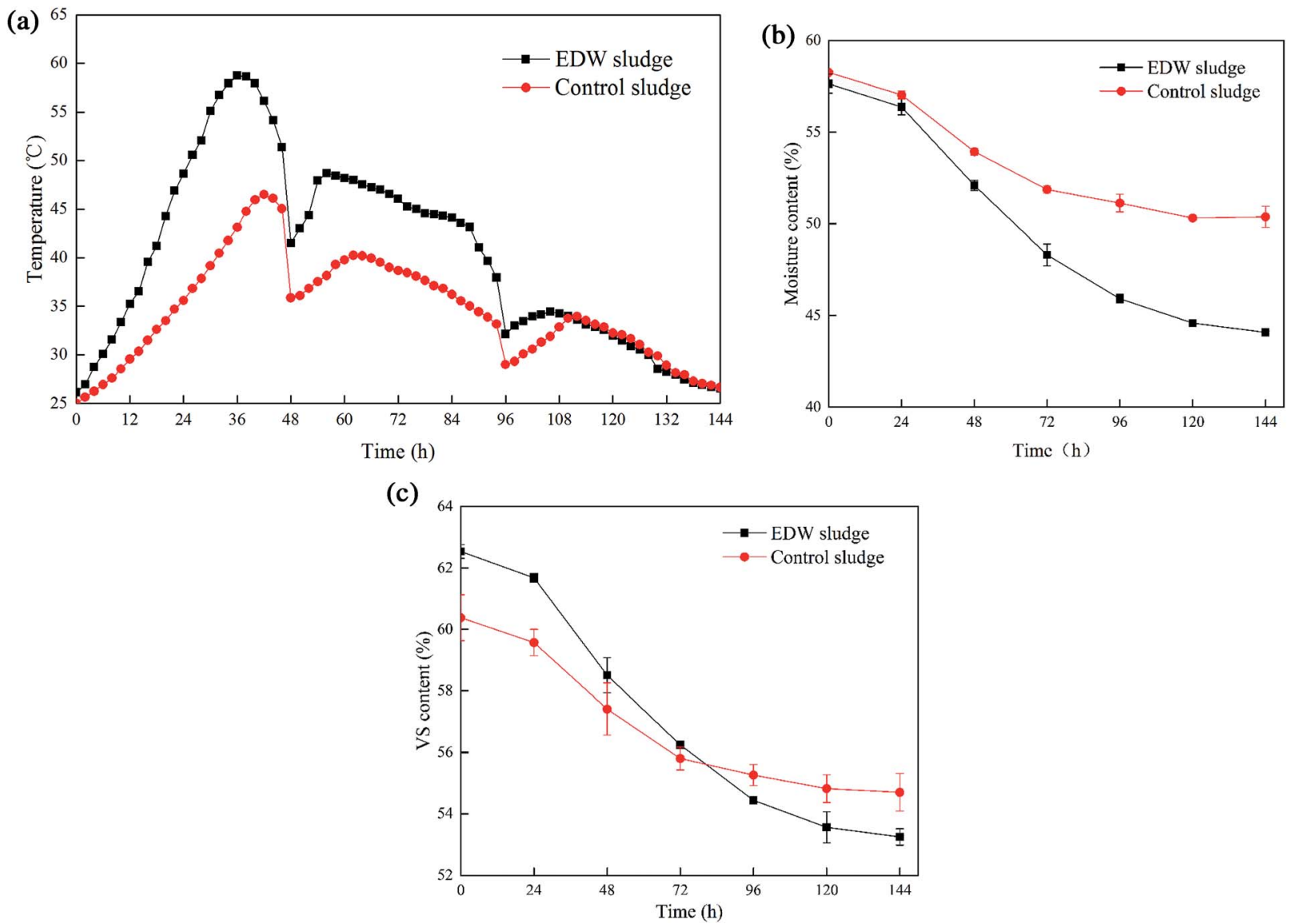

Fig. 5 Variation of (a) temperature, (b) MC, and (c) VS content in EDW sludge and control sludge during bio-drying.

water can be easily removed. The results also clearly show that during the $144 \mathrm{~h}$, the VS content of sludge pile after EDW decreased by $9.3 \%$, whereas the VS content of the control sludge pile decreased by $5.7 \%$ (Fig. 5c). This is because in EDW sludge, an increased number of active microorganisms consumed more organic matter, along with a large amount of bio-heat, and it resulted in higher temperature and lower water content in the bio-drying process (seen in Fig. $5 \mathrm{a}$ and b). Villegas et al. ${ }^{42}$ also confirmed that the generation of bio-heat was dependent on the degradation of organic matter. As mentioned above, an EDW pretreatment of sludge improved the bio-drying process.

\subsection{Effect of bulking agents during bio-drying}

During the bio-drying process, adding bulking agents is widely implemented to improve the size and number of inter-particle voids in the pile, leading to its increased permeability to air, and decrease of the amount of (or completely avoid) leachate production. ${ }^{43,44}$ In the tests, EDW sludge, bulking agents, and $\mathrm{CP}$ were mixed in a mass ratio of $15: 3: 5$, and the EDW sludge was pretreated at the electric field strength of $20 \mathrm{~V} \mathrm{~cm}^{-1}$. Simultaneously, sludge after EDW with no bulking agent was prepared as the control. As shown in Fig. 6a, adding the bulking agent potentially improved the bio-drying process. A higher drying rate was obtained when the bulking agent was straw, and the first peak temperature of the pile with straw was $13.2^{\circ} \mathrm{C}$ and $22.9^{\circ} \mathrm{C}$ higher than that of the piles with sawdust and plastic foam, respectively. After the first homogenization of sludge, the pile with straw still exhibited a good drying trend, with second peak temperatures being $10.7{ }^{\circ} \mathrm{C}$ and $15.0^{\circ} \mathrm{C}$ higher than the piles with sawdust and plastic foam, respectively. After the second homogenization of sludge, the temperature of the pile with straw increased slightly to a third peak temperature of $34.5{ }^{\circ} \mathrm{C}$, while the temperatures of piles with sawdust and plastic foam did not change significantly. During the bio-drying process, the water from sludge caused by microbial metabolism was absorbed by straw at most, followed by sawdust, and the plastic foam was the weakest. A low metabolic water accumulation would lead to an increase the porosity of the pile and the mass transfer rate between microorganisms and oxygen, enhancing microbial activity and increasing the temperature of the pile. Furthermore, according to the previous reports, straw has a substantial biodegradation potential during the aerobic process, and more biodegradable organic matter generates more heat, resulting in a higher temperature, which in turn, enhances organic matter degradation. ${ }^{45}$

Both the MC and VS contents decreased with time (Fig. 6b and c). After $144 \mathrm{~h}$, the MC of the pile with straw, sawdust, and plastic foam decreased by $13.6 \%, 8.3 \%$, and $5.0 \%$, respectively, while the VS content decreased by $9.3 \%, 4.5 \%$, and $2.8 \%$, respectively. The MC and VS content of the pile with straw 

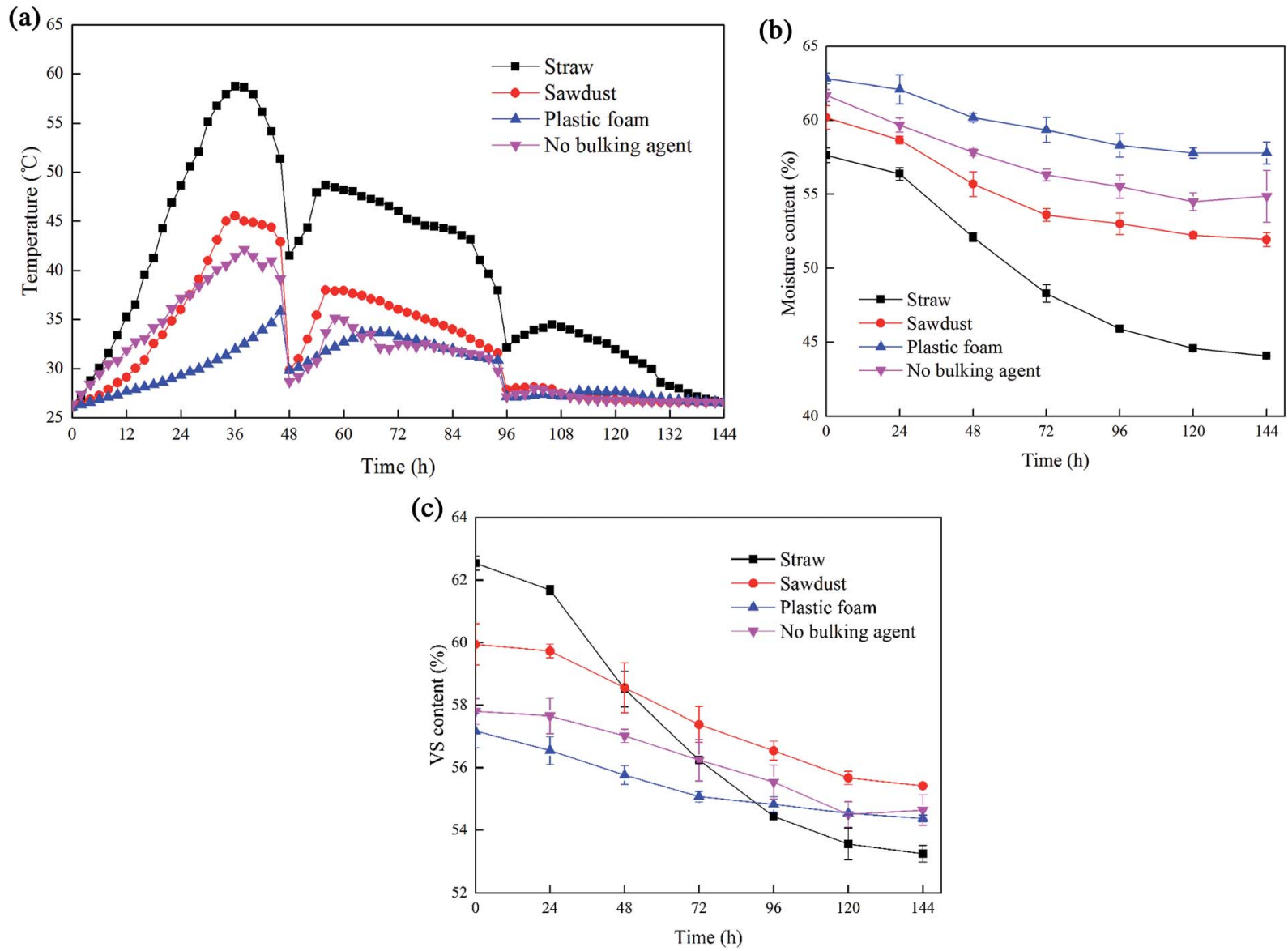

Fig. 6 Effect of bulking agents on (a) temperature, (b) MC, and (c) VS content during bio-drying.

arrived at $44.1 \%$ and $53.2 \%$, respectively. According to the temperature curve, the high temperature of the pile with straw could promote water evaporation. Moreover, only the pile with straw reached the temperature values of the thermophilic phase $\left(T>50{ }^{\circ} \mathrm{C}\right)$. Thermophilic phase with the highest microbial activities displayed maximum organic matter decomposition. ${ }^{14}$ Furthermore, at the end of the experiment, a large amount of free water was found in the pores of the pile with plastic foam. This accumulation of water affected heat transfer and mass transfer; thus, temperature, MC and VS of the pile with plastic foam exhibited no significant changes.

\subsection{Energy and cost analysis}

3.4.1 Energy consumption and optimization of EB process. The comparison of energy consumption between EDW process and EB process is shown in Fig. 7. The energy consumption of EDW process, $W_{\mathrm{ED}}$, is expressed by eqn (a):

$$
W_{\mathrm{ED}}=\frac{W}{m_{\text {filt }}}=\frac{1}{m_{\text {filt }}} \int U I \mathrm{~d} t
$$

where $W$ is energy consumption $(\mathrm{kW} \mathrm{h})$ and $m_{\text {filt }}$ is the average mass of filtrate removed $(\mathrm{kg}), U$ is the applied electric potential $(\mathrm{V})$ and $I$ is the average current (A). The energy consumption of bio-drying of EB process, $W_{\mathrm{BD}}$, is expressed by eqn (b):

$$
W_{\mathrm{BD}}=\frac{W}{m_{\text {filt }}}=\frac{1}{m_{\text {filt }}} \int P \mathrm{~d} t
$$

where $P$ is power of air pump in the aeration process $(9 \mathrm{~W})$.

When the MC of sludge was lower than $65 \%$, energy consumption of EDW process began to increase significantly. EDW process reached the dewatering limit when the MC of

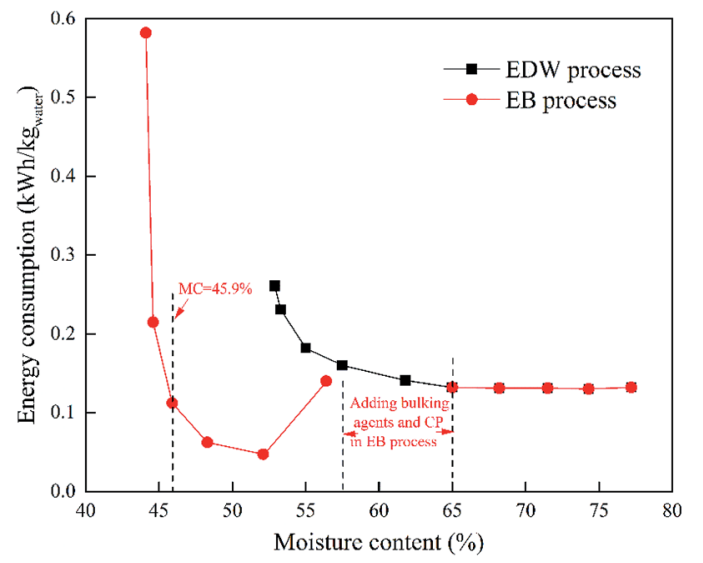

Fig. 7 Comparison of energy consumption between EDW process and EB process. 
Table 1 Comparison of moisture content, treatment time, energy consumption, and cost of EB process, thermal drying, composting, and lime drying

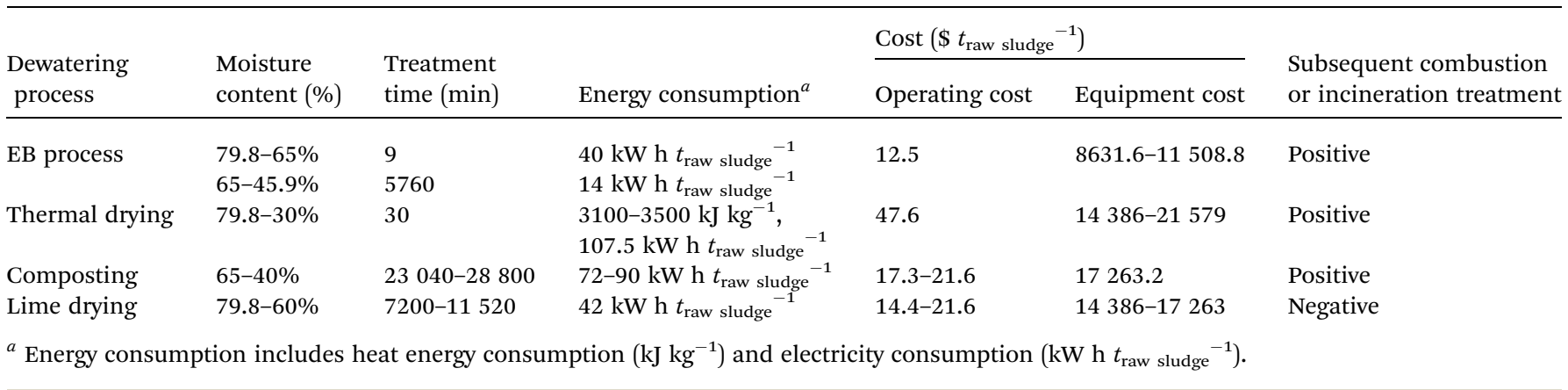

sludge was $52.9 \%$, and the energy consumption was as high as $0.261 \mathrm{~kW} \mathrm{~h} \mathrm{~kg}_{\text {water }}{ }^{-1}$. In bio-drying stage of EB process, energy consumption was maintained at a relatively low level when the MC was 56.4-45.9\%. However, energy consumption increased sharply when the MC reached $44.1-45.9 \%$. It was due to the reduction in heat production with the decrease of the $\mathrm{MC}$, but input of power consumption because of aeration still continued. In the last $48 \mathrm{~h}$ of bio-drying, the MC of sludge decreased by only $1.5 \%$ but the energy consumption increased by $0.47 \mathrm{~kW} \mathrm{~h} \mathrm{~kg}_{\text {water }}{ }^{-1}$. Therefore, $96 \mathrm{~h}$ of the optimal bio-drying time was chosen in EB process.

3.4.2 Energy and cost of different dewatering process. The energy consumption and costs of EB process, thermal drying, composting and lime drying were compared (Table 1). The operating and equipment costs of EB process were the lowest, at approximately $\$ 12.5$ and $\$$ 8631.6-11 508.8, respectively. Thermal drying is very effective for deeper dewatering of sludge, wherein the MC decreased from $79.8 \%$ to $30 \%$ for $30 \mathrm{~min}$. However, it had the highest energy consumption, operation costs, and equipment costs, which were approximately 2.0 (only electricity consumption), 3.8 and 1.2-2.5 times than those of the EB process, respectively. The energy consumption of lime drying was only $42 \mathrm{~kW} \mathrm{~h} t_{\text {raw sludge }}{ }^{-1}$, which was $22.2 \%$ less than that of the EB process. However, the operation costs and equipment costs were approximately $1.2-1.7$ and 1.2-2 times than those of the EB process, respectively. Dried sludge can not only be used as a renewable fuel replacing fossil fuels, but also it can be made into building materials such as bricks. Different dewatering processes affect the downstream resource utilization of sludge. In the last column of Table 1, 'positive' indicates that the dewatering process was beneficial for subsequent incineration and combustion treatment and 'negative' indicates the opposite. During the EB process, thermal drying, and composting, no chemical additives produced toxic substances in subsequent combustion or incineration processes. The three dewatering processes mentioned above can turn the sludge into solid recovered fuel, which can be combusted for energy production or replace other fuels in industrial processes. ${ }^{46}$ In addition, quality of cement and brick with lime-added sludge is poor, and lime explodes during the process. ${ }^{47}$ Thus, adding lime to sludge is disadvantageous for subsequent combustion or incineration treatment. The present analysis showed that the
EB process is an environmentally friendly, energy-saving, and low-cost sludge dehydration process.

\section{Conclusions}

Bio-drying is an energy-saving technology for deep dewatering of sludge. However, sludge dewatered mechanically cannot be treated by bio-drying alone because of the low gas permeability resulting from its high MC and small particle size. In this study, EDW, as an electrokinetic pretreatment to improve the biodrying process, was investigated. It was found that EDW could improve the bio-drying process. EDW was able to increase the drying rate and decrease the final water content of sludge, resulting from increased microbial activity that caused the consumption of more degradable organics and produced more bio-heat. Lowering the applied electric field strength is proposed to increase microbial activity and to reduce the damage to microbial cells and EPS of sludge. The results also reveal that EDW sludge incorporating straw as a bulking agent is a good approach for bio-drying process with lower energy consumption and cost.

\section{Conflicts of interest}

There are no conflicts to declare.

\section{Acknowledgements}

This research is supported by the National Natural Science Foundation of China (51608247).

\section{References}

1 J. Jiang, Q. Zhao, J. Zhang, G. Zhang and D. J. Lee, Bioresour. Technol., 2009, 100, 5808-5812.

2 X. Qian, Y. Wang and H. Zheng, Water Res., 2016, 88, 93-103. 3 A. Mahmoud, A. F. A. Hoadley, J. B. Conrardy, J. Olivier and J. Vaxelaire, Water Res., 2016, 103, 109-123.

4 L. Cai, T. B. Chen, D. Gao and J. Yu, Water Res., 2015, 90, 4451.

5 S. Visigalli, A. Turolla, H. Zhang, P. Gronchi and R. Canziani, J. Environ. Chem. Eng., 2017, 5, 6122-6131. 
6 S. Heimersson, M. Svanström, C. Cederberg and G. Peters, Resour., Conserv. Recycl., 2017, 122, 126-134.

7 A. Mahmoud, A. Hoadley, M. Citeau, J. M. Sorbet, G. Olivier, J. Vaxelaire and J. Olivier, Water Res., 2018, 129, 66-82.

$8 \mathrm{~J}$. Vaxelaire, J. M. Bongiovanni, P. Mousques and J. R. Puiggali, Water Res., 2000, 34, 4318-4323.

9 L. Zhao, W. M. Gu, P. J. He and L. M. Shao, Water Res., 2010, 44, 6144-6152.

10 H. Liu, H. Xiao, B. Fu and H. Liu, Chem. Eng. J., 2017, 313, 655-662.

$11 \mathrm{~W}$. Ke, Y. Wu, W. Zhe, W. Wei and N. Ren, Bioresour. Technol., 2018, 265, 25-32.

12 F. Tambone, B. Scaglia, S. Scotti and F. Adani, Bioresour. Technol., 2011, 102, 7443-7450.

13 Q. Li, X. Lu, H. Guo, Z. Yang, Y. Li, S. Zhi and K. Zhang, Bioresour. Technol., 2018, 263, 94-102.

14 X. L. Zhao, L. I. Bi-Qiong, N. I. Jiu-Pai and D. T. Xie, J. Integr. Agric., 2016, 15, 232-240.

15 A. Mahmoud, J. Olivier, J. Vaxelaire and A. F. Hoadley, Water Res., 2010, 44, 2381-2407.

16 A. Mahmoud, J. Olivier, J. Vaxelaire and A. F. Hoadley, Water Res., 2011, 45, 2795-2810.

17 J. L. Feng, Z. H. Zhao, F. Chen and H. P. Hu, J. Volcanol. Geotherm. Res., 2014, 287, 1-11.

18 M. H. M. Raats, A. J. G. V. Diemen, J. Lavèn and H. N. Stein, Colloids Surf., A, 2002, 210, 231-241.

19 H. Xu, K. Shen, T. Ding, J. Cui, M. Ding and C. Lu, Chem. Eng. J., 2016, 293, 207-215.

20 J. Olivier, J. B. Conrardy, A. Mahmoud and J. Vaxelaire, Water Res., 2015, 82, 66-77.

21 X. Y. Yu, S. T. Zhang, L. Zheng, Y. Liu and H. Xu, Trans. Tianjin Univ., 2011, 17, 39-44.

22 J. B. Conrardy, J. Vaxelaire and J. Olivier, Water Res., 2016, 100, 194-200.

23 T. Navab-Daneshmand, R. Beton, R. J. Hill, R. Gehr and D. Frigon, Water Res., 2012, 46, 3999-4008.

24 S. Zhang, Z. Yang, X. Lv, S. Zhi, Y. Wang, Q. Li and K. Zhang, Chem. Eng. Res. Des., 2017, 121, 44-56.

25 L. C. Hua, C. Huang, Y. C. Su, T. N. P. Nguyen and P. C. Chen, J. Membr. Sci., 2015, 495, 29-36.

26 S. S. Yang, W. Q. Guo, G. L. Cao, H. S. Zheng and N. Q. Ren, Bioresour. Technol., 2012, 124, 347-354.
27 Z. G. Liu, Z. H. Ruan, Y. Xiao, Y. Yi, Y. J. J. Tang, W. Liao and Y. Liu, Bioresour. Technol., 2013, 132, 166-170.

28 H. P. Yuan, X. F. Yan, C. F. Yang and N. W. Zhu, J. Hazard. Mater., 2011, 187, 82-88.

29 Q. Yu, X. Jin and Y. Zhang, Water Res., 2018, 135, 44-56.

30 B. Cao, W. Zhang, Y. Du, R. Wang, S. P. Usher, P. J. Scales and D. Wang, Water Res., 2018, 130, 363-375.

31 B. Yu, J. Xu, H. Yuan, Z. Lou, J. Lin and N. Zhu, Fuel, 2014, 130, 279-285.

32 J. Zhang, J. Zhang, Y. Tian, N. Li, L. Kong, L. Sun, M. Yu and W. Zuo, Chem. Eng. J., 2016, 301, 238-248.

33 L. C. Hua, C. Huang, Y. C. Su, T. N. P. Nguyen and P. C. Chen, J. Membr. Sci., 2015, 495, 29-36.

34 D. Boruszko, Environ. Res., 2017, 155, 344-352.

35 K. Nakanishi, H. Tokuda, T. Soga, T. Yoshinaga and M. Takeda, J. Ferment. Bioeng., 1998, 85, 250-253.

36 S. Ibeid, M. Elektorowicz and J. A. Oleszkiewicz, Water Res., 2013, 47, 903-910.

37 X. Shi, X. Guo, J. Zuo, Y. Wang and M. Zhang, Waste Manag., 2018, 75, 261-269.

38 M. A. Rahman, H. B. Møller, C. K. Saha, M. M. Alam, R. Wahid and L. Feng, Renewable Energy, 2018, 128, 241-249.

39 R. Lin, J. Cheng, L. Ding and J. D. Murphy, Chem. Eng. J., 2018, 350, 681-691.

40 J. Ma, L. Zhang, L. Mu, K. Zhu and A. Li, Waste Manag., 2018, 80, 327-338.

41 C. A. Velis, P. J. Longhurst, G. H. Drew, R. Smith and S. J. T. Pollard, Bioresour. Technol., 2009, 100, 2747-2761.

42 M. Villegas and C. Huiliãir, Bioresour. Technol., 2014, 174, 33-41.

43 F. Yang, G. X. Li, Q. Y. Yang and W. H. Luo, Chemosphere, 2013, 93, 1393-1399.

44 J. Yuan, Q. Yang, Z. Zhang, G. Li, W. Luo and D. Zhang, J. Environ. Sci., 2015, 37, 83-90.

45 L. Zhao, W. M. Gu, P. J. He and L. M. Shao, Water Res., 2011, 45, 2322-2330.

46 A. Papageorgiou, J. R. Barton and A. Karagiannidis, J. Environ. Manage., 2009, 90, 2999-3012.

47 B. Rao, Y. Zhu, M. Yu, X. Lu, Y. Wan, G. Huang, X. Su and X. Liu, Process Saf. Environ. Prot., 2019, 122, 288-297. 